\title{
Two castes sizes of leafcutter ants in task partitioning in foraging activity
}

\author{
Participação de dois tamanhos de castas de operárias de formigas cortadeiras no particionamento \\ de tarefas da atividade de forrageamento
}

\author{
Marcelo Arruda de Toledo $^{\mathrm{I}^{*}}$ Pedro Leite Ribeiro ${ }^{\mathrm{I}}$ Priscilla Shiota Fedichina Carrossoni $^{\mathrm{I}}$ \\ João Vitor Tomotani' ${ }^{I}$ Ashley Nicole Hoffman ${ }^{I I}$ Daniella Klebaner ${ }^{I I}$ Halee Rachel Watel ${ }^{\text {II }}$ \\ Carlos Arturo Navas Iannini ${ }^{I}$ André Frazão Helene ${ }^{I}$
}

\section{ABSTRACT}

Task partitioning in eusocial animals is most likely an evolutionary adaptation that optimizes the efficiency of the colony to grow and reproduce. It was investigated indirect task partitioning in two castes sizes; this involves task partitioning in which the material transported is not transferred directly from one individual to another, but where it is dropped by one ant to be picked up by another. In two separate approaches, it was confirmed previous results pertaining to leaf caching activities among Atta colombica with task partitioning activities involving leaf dropping among Atta sexdens rubropilosa, in which there is a correlation between the size of an individual ant and the leaf fragment it transports. It was also suggested that this correlation exists only in individual ants that cut and transport (CaT) the same fragment to the nest. When task partitioning occurs and individual ants transporting (T) leaf fragments cut by other ants, the correlation becomes looser or disappears. We also observed that CaT ants are smaller than $T$ ants.

Key words: Atta, ant behavior, leaf cutting, ecological adaptation. RESUMO

Particionamento de tarefas em animais eusociais é provavelmente uma adaptação evolutiva, que otimiza a eficiencia de forrageio da colonia, gerando maior capacidade de crescimento e reprodução. Nós investigamos o particionamento indireto de tarefas, com onvolvimento de castas de dois tamanhos distintos. Assim, o material coletado por uma formiga não era transportado diretamente ao ninho, nem transferido diretamente de um indivíduo para outro, mas sim descartado por uma formiga e coletado por outra. Em duas abordagens distintas, nós confirmamos em Atta sexdens rubropilosa resultados anteriores relativos à ocorrência deste particionamento indireto de tarefas, observado em Atta colombica. Mostramos também que, assim como em Atta colombica, há uma correlação entre os tamanhos da formiga e do fragmento de folha transportado quando esta corta e transporta este fragmento ao ninho (CaT). Mais ainda confirmamos em Atta sexdens que, quando o particionamento de tarefas ocorre e as formigas apenas transportam o fragmento de folhas (T) cortadas por outras formigas, a correlação desaparece. Nós também descrevemos que as formigas CaT são menores do que as $T$.

Palavras-chave: Atta, o comportamento das formigas, o corte de folha, adaptação ecológica.

\section{INTRODUCTION}

Ants are eusocial insects that depend on the highly developed social structures to express their ecological relationships. The understanding of those intrinsic aspects, specially related to basic maintenance of colony must contribute to understand ecological consequences.

Task division in eusocial animals likely results from adaptations enhancing survival and reproduction (WILSON, 1971). Task partitioning is defined as the division of tasks into two or more subtasks; the passing of a piece of leaf from one worker to another is an example of task partitioning (HART et al., 2002). Some species of social insects, especially some ants, are adapted to their respective tasks through morphological differentiation within the colony, physical castes (OSTER \& WILSON, 1978) with higher probability of a certain caste engaging

\footnotetext{
'Departamento de Fisiologia, Instituto de Biociências, Universidade de São Paulo (USP), Rua do Matão, trav. 14, n 321 , Cidade Universitária, 05508-090, São Paulo, SP, Brasil. E-mail: afh@ib.usp.br. *Corresponding author.

IVanderbilt University Nashville, Tennessee, United States of America.
} 
in a certain task (WILSON, 1980a). Morphological differentiation may be a result of evolutionary optimization of colony performance, enhancing task efficiency and fitness (OSTER \& WILSON, 1978; HELANTERA \& RATNIEKS, 2008). However, morphology, behavior and task partitioning reinforce the behavior of the entire colony as an inseparable one-to-one relationship.

This plasticity is particularly important in leafcutter ants, especially those of the genus Atta, which encompasses the most extreme examples of intra-colony phenotypic diversity in ants. A typical Atta colony includes individuals across a size continuum, from tiny ants that tend the fungus garden to large ants that are specialized in defense and are about one order of magnitude larger (WILSON, 1971). In Atta ant colonies, the relationship between size and task division must be complex, particularly when considering the partitioning of a task into sub-tasks (ANDERSON \& RATNIEKS, 1999; RATNIEKS \& ANDERSON, 1999; HART \& RATNIEKS, 2001a, 2001b; HART et al., 2002; BURD \& HOWARD, 2008).

In Attini ants, task partitioning is particularly evident in their foraging activities, including finding, cutting and transporting leaves (FOURCASSIE et al., 2010) These three tasks must be carried out as an integrated process, which requires complex interrelationships among individual ants (BURD \& ARANWELA, 2003; DUSSUTOUR et al., 2009; FOURCASSIE et al., 2010). Factors such as distance to food sources, properties of the terrain and quality of available resources may affect the demands imposed by these tasks and the need for inter-individual interactions (LOPES et al., 2003; RÖSCHARD \& ROCES, 2003a, 2003b; CLARK, 2006; LEWIS et al., 2008; MOLL et al., 2012). Accordingly, task partitioning may be better interpreted as a flexible process that is influenced by context-specific nuances. For example, Acromyrmex ants may transfer leaf fragments from one ant to another in the middle of the trail, thus apparently enhancing foraging efficiency (LOPES et al., 2003).

The idea of task partitioning was originally proposed by JEANNE (1986) and later refined by RATNIEKS \& ANDERSON (1999). According to RATNIEKS \& ANDERSON (1999) task partitioning can occur both directly and indirectly. The first case occurs when one individual directly transfers material to another one. Task partitioning would be indirect if this transfer of material occurs without direct interaction, for example when some workers cut leaves and deposit fragments at a given location and other workers take and transport them into the colony (RATNIEKS \& ANDERSON, 1999; HART et al., 2002). However, indirect task partitioning can happen in two different ways. One involves the formation of leaf caches at different points along the trail, especially at the nest entrance. This example was extensively studied by HART \& RATNIEKS (2001b), who reported that the size of ants that cut pieces of leaves correlates positively with the size of the leaf that was cut. However, the size of ants that receive an already-cut piece of leaf from a leaf cache presented no correlation to the size of the piece of leaf itself. The other possibility of indirect task partitioning occurs in the context of leaf dropping, a process in which some individuals cut the leaf and transport it part-way back to the nest and then release the fragments (HART \& RATNIEKS, 2001b) or when they release the fragment just after cutting it, so that other ants transport it.

The purpose of this study was to contribute to understand the organization of foraging on leaf cutting ants. We intended to do that considering size matching, as observed by HART \& RATNIEKS (2001b), and the involvement of two different ant caste sizes in the organization of task partitioning, thus enhancing discussion on behavior strategies and ecological adaptation. Accordingly, it was investigate indirect task partitioning involving two caste sizes of Atta sexdens rubropilosa Forel, 1908 (Hymenoptera: Formicidae).

\section{MATERIALS AND METHODS}

Colonies

It was used a 3 year-old or older natural, healthy and active colony of Atta sexdens rubropilosa located on the campus of the Universidade de São Paulo and three vigorous four-year-old colonies raised in captivity, with approximately 40 thousand ants each.

\section{General approach}

Two approaches were applied: an observation of a natural colony and an experiment done in the laboratory. Measurement of a natural colony aimed to establish a correlation between ant size and the size of leaf fragments being carried. For the same 1 hour each morning, over 6 consecutive days, it was collected all ants returning to a specific nest entrance. We collected a total of 183 leaf-transporting ants, as follows: 32 ants on day $1 ; 39$ on day $2 ; 30$ on day $3 ; 27$ on day 4 ; 26 on day 5 ; and 29 on day 6 . We then measured 
cephalic size (head capsule width) and respective leaf fragment area.

In the laboratory experiment, it was investigated the existence of correlations between the cephalic size of ants and the size of leaf fragments being carried for ants known to have cut the fragments themselves (CaT), and for those known to transport fragments that they had not cut themselves (T). This experiment was done only in the laboratory where it could be observed the foraging place and the trail at the same time.

It was placed a $1 \mathrm{~m}$ long bridge leading from the nest to the foraging tray, where Acalypha leaves were offered ad libitum. For three hours per day, on two subsequent days, it was collected ants as soon as they had been unambiguously characterized as CaT or T. To avoid double sampling all ants that could be characterized as CaT or T were collected.

For our experiment, leaf dropping was defined as a behavior in which ants that cut a piece of leaf dropped it on the foraging area, without transporting it at all. We replicated the laboratory experiment with three different colonies; therefore, we have trials 1,2 and 3. In total, we obtained 155 $\mathrm{CaT}$ and $170 \mathrm{~T}$ ants.

Analysis

We scanned leaf fragments and ant's heads (without antennas) and then used a MATLAB routine designed to measure the areas of leaf fragments and head widths, to $0.2 \mathrm{~mm}$ precision. For both experiments, it was calculated the Pearson's correlation between the cephalic size of ants and leaf area, and to check whether the observed correlation was significant. The correlation values were transformed using a Student's $\mathrm{t}$ distribution. In laboratory experiment a $2 \times 3$ ANOVA was applied to evaluate the effects of function (CaT and $\mathrm{T}$ ) and trial (1,2 and 3).

\section{RESULTS}

Observation and measurement of a natural colony: cephalic size ranged between $1.0 \mathrm{~mm}$ and $5.1 \mathrm{~mm}\left(\mathrm{MEAN}^{+}\right.$S.E. of $\left.2.76+0.06 \mathrm{~mm}\right)$, and the larger ants carried larger fragments (correlation, rho $=0.5002, \mathrm{P}<0.0001$; Figure 1).

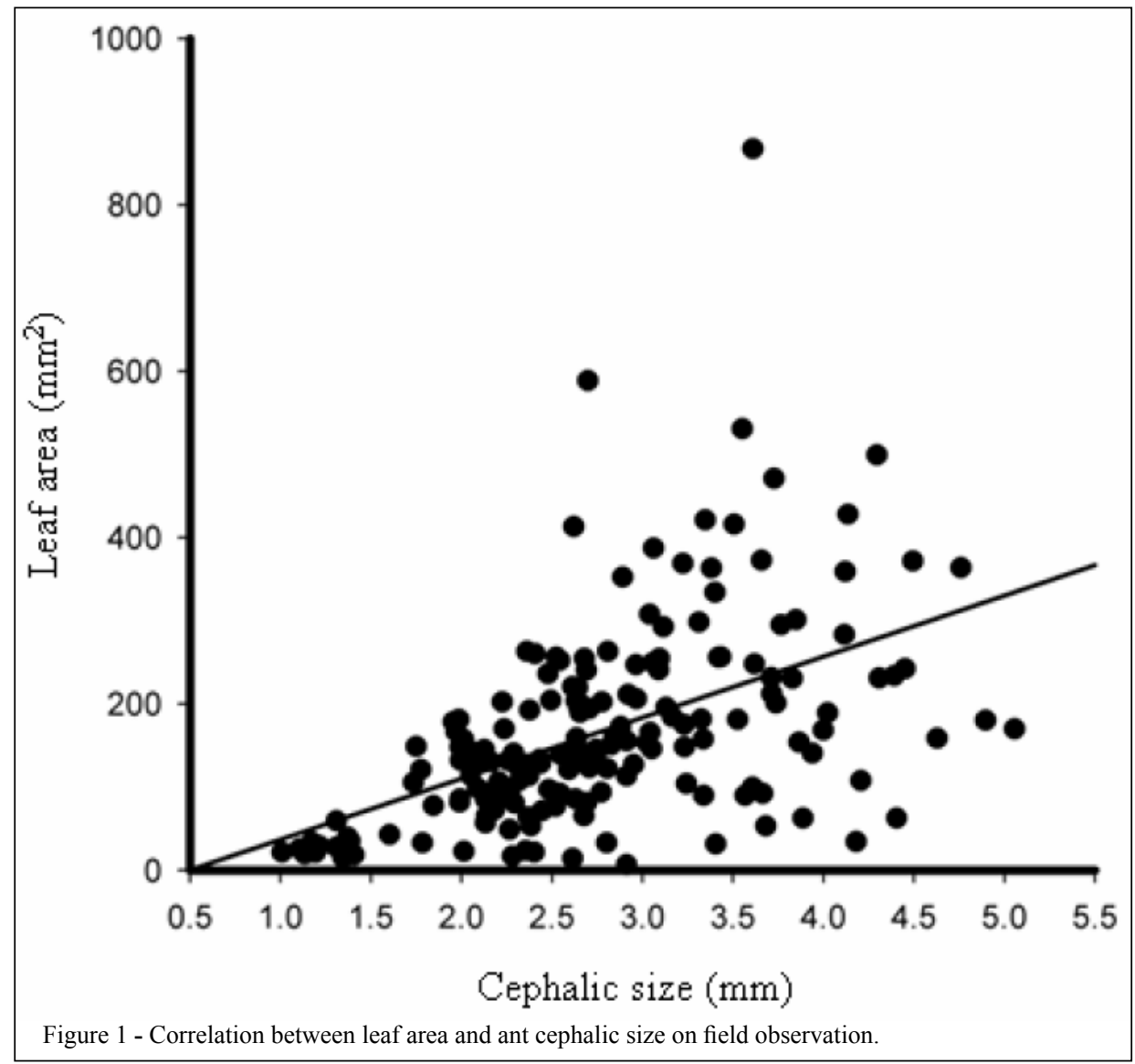

Ciência Rural, v.46, n.11, nov, 2016. 
In the laboratory experiment, it was reported a positive correlation between ant size and leaf fragments for ants that cut and transport (CaT) ants in all three trials of the experiment (Trial 1: correlation, rho $=0.8250, \mathrm{P}<0.0001$; Trial 2: correlation, rho $=0.4048, \mathrm{P}=0.0004$; and Trial 3 : correlation, rho $=0.4591, \mathrm{P}=0.0022$; Figure 2). However, this relationship between ant size and fragment size was absent in two trials for the ants that only transport $(\mathrm{T})$ (Trial 1, correlation, rho $=-0.0671, \mathrm{P}=0.6848$ and Trial 2, correlation, rho $=-0.0954, \mathrm{P}=0.5745)$; a negative correlation emerged in Trial 3 (correlation, rho $=-0.2301$, $\mathrm{P}=0.0273$; Figure 2). It was also reported in the laboratory experiment that the cephalic sizes of ants in different trials were similar (ANOVA effect of trial, $\left.\mathrm{F}_{(2,319)}=2.30, \mathrm{P}=0.1017\right)$, but the sizes of $\mathrm{T}$ and $\mathrm{CaT}$ ants were different (ANOVA - effect of function, $\left.\mathrm{F}_{(1,317)}=17,46, \mathrm{P}<0.0001\right)$. However, the difference in the size of $\mathrm{CaT}$ and $\mathrm{T}$ ants is different in different trials (ANOVA - interaction function $\mathrm{x}$ trial $\mathrm{F}_{(2,319)}=5,58, \mathrm{P}=0.0042$; Figure 3).

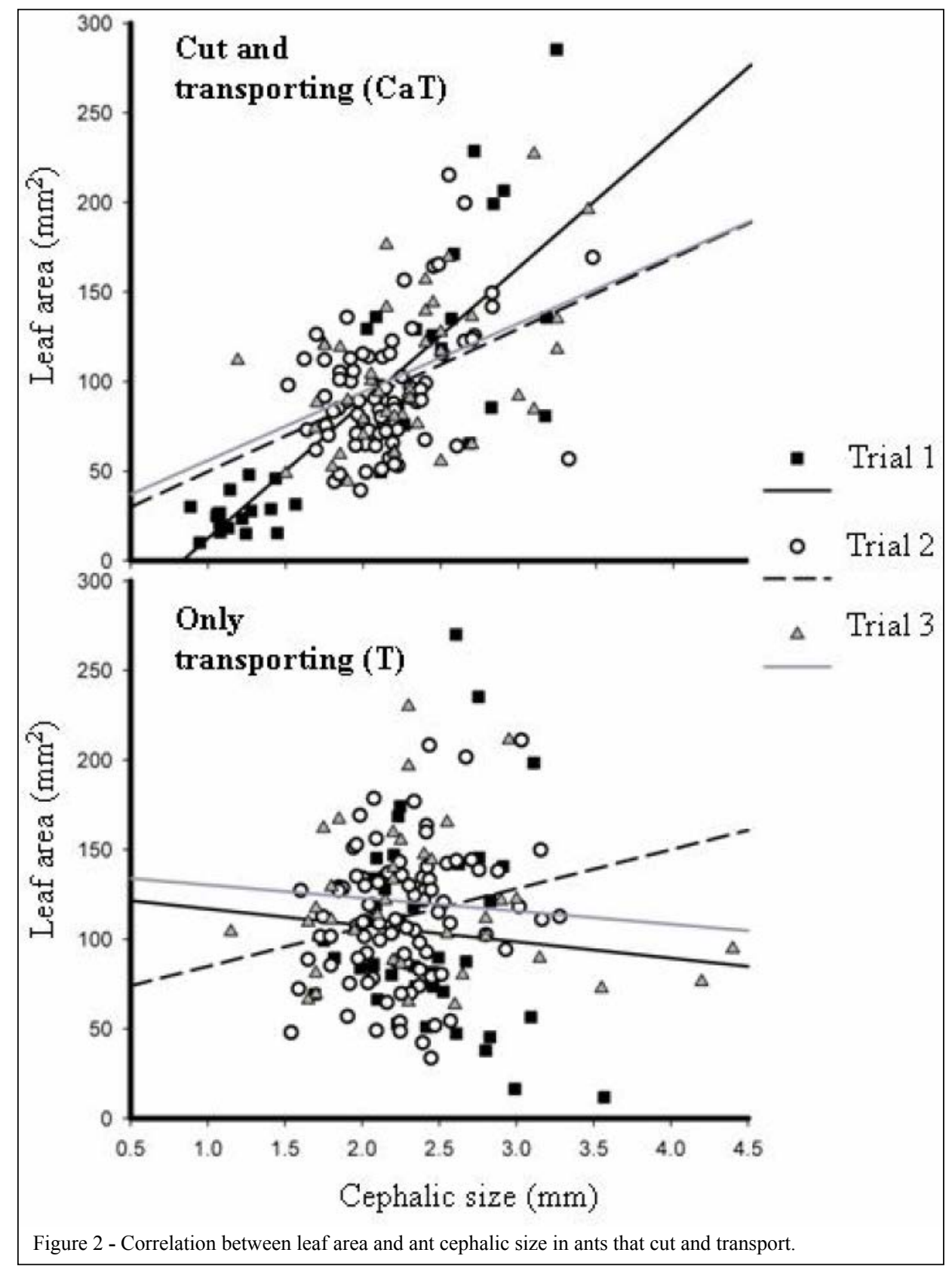

Ciência Rural, v.46, n.11, nov, 2016. 


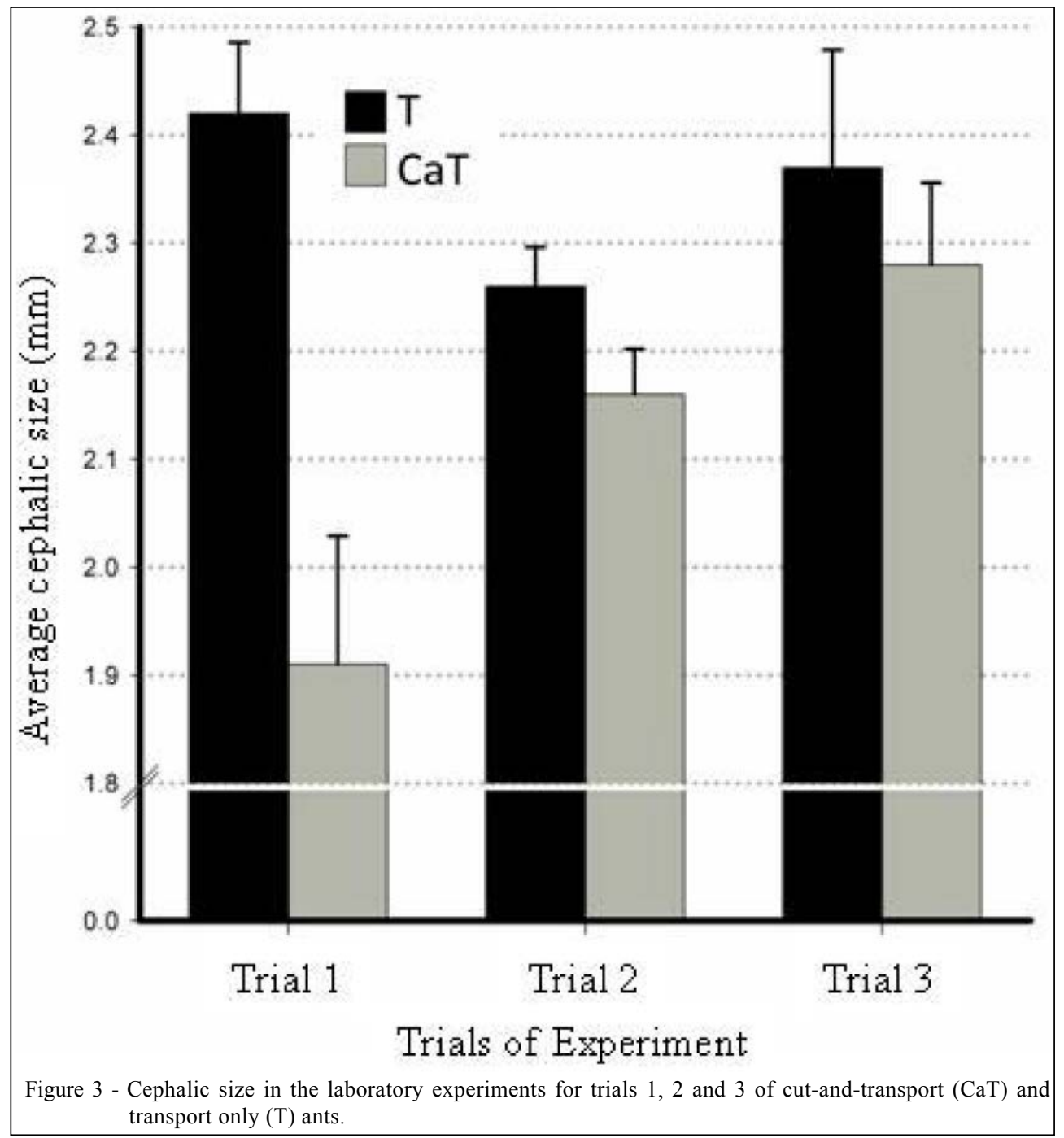

\section{DISCUSSION}

Results reinforce that understanding task partitioning is necessary to understand ant foraging as collective behavior. Results also showed that the ants that transport but don't cut $(\mathrm{T})$ were larger than those which did both (CaT ants). In this context, our study provides new discoveries about the task partitioning process with regards to the leaf cutting and transporting process undertaken by $\boldsymbol{A t t a}$. This data can contribute to the understanding of task partitioning during foraging activity (WILSON, 1980b; HOLLDOBLER \& WILSON, 1990; BURD, 1995, 2000; EVISON \& RATNIEKS, 2007; BOLLAZZI \& ROCES, 2011).

When a three dimensional food source, such as a mango, is offered, the larger ants become responsible for cutting fragments while the smaller ants carry those (EVISON \& RATNIEKS, 2007). However, when a simple bi-dimensional item is offered, larger ants seem to be more devoted to carrying rather than cutting as we show in this study. This behavioral plasticity among individuals, which enables task partitioning, may result from adaptations that improve the efficiency of foraging activities in the colony as a whole (OSTER \& WILSON, 1978; BURD, 1995, 1996, 2000). This idea has been explored empirically (HELANTERA \& RATNIEKS, 2008) in several contexts; for example, the distance from the nest, the hardness and thickness of leaves and the shape of the fragments (ROCES, 1990; RÖSCHARD \& ROCES, 2003a; BURD, 2001; MOLL et al., 2012).

Indirect task partitioning in the foraging activities of leafcutter ants is likely to be adaptive in the context of leaf cache formation, but, according to HART \& RATNIEKS (2001b), it is not necessary

Ciência Rural, v.46, n.11, nov, 2016. 
for leaf dropping. However the results suggest that task partitioning in foraging activities involving leaf dropping among Atta may also be adaptive. Since smaller ants are better at cutting and transporting leaves, larger ants only transport them, so the fact that different morphological groups of ants execute different tasks is a strong sign of adaptability (HOLLDOBLER \& WILSON, 1990). Our results reinforce the idea already presented by FOWLER \& ROBISON (1979). However, the behavior of leaf dropping reported by FOWLER \& ROBISON (1979) involves tree climbing, where the leaves were dropped from. In that context, the energy saved is more evident, once the leaf may be dropped from several meters. In our study the energy gain is not so evident and even so the behavior happens. So we understand that this reinforce the idea that this task partitioning is an intrinsic behavior of foraging, as suggested by FOWLER \& ROBISON (1979). Because task partitioning is an intrinsic characteristic of the foraging behavior of ants, it must be considered from different perspectives. RUDOLPH \& LOUDON (1986) proved that ants tend to transport leaves that are smaller than expected from the exclusive stand point of maximum efficiency. The lack of maximum efficiency can be a consequence of the fact that larger ants transport leaves cut by smaller ones; therefore, transporting smaller leaves could be expected if they had cut them themselves (WETTERER, 1991). Task partitioning among $\mathrm{CaT}$ and $\mathrm{T}$ ants could account for the lack of individual optimization as observed earlier (RUDOLPH \& LOUDON, 1986). Furthermore, larger ants are faster, and the fact that they are usually involved in transporting tasks agrees with the ideas proposed by BOLLAZZI \& ROCES (2011). Other aspects may determine the relation between ant and leaf size, especially in the group of ants that cut and transport, as suggested by the large variability associated with the mean leaf size carried by larger ants.

Even though foraging involves activities performed outside the nest, it is possible that is affected by activities inside the nest, as leaf implantation (BURD \& HOWARD, 2008). Large ants are less apt to implant leaf fragments in the fungus gardens (HOLLDOBLER \& WILSON, 1990), so transferring fragments to smaller ants may be part of the natural colony's foraging tasks. If fragment size depends on ant size (WETTERER, 1991), large fragments would increase implantation cost because supplementary cutting would be needed (BURD \& HOWARD, 2008). Therefore, different aspects of cutting process can only be understood from a wide-ranging analysis of foraging behavior that includes task partitioning, contextual elements and probably leaf implantation. In this context it is possible to observe that a profound understanding of ecological aspects can only be understood considering different aspects of ant's biology.

\section{ACKNOWLEDGEMENTS}

Financial support by Fundação de Amparo à Pesquisa do Estado de São Paulo (FAPESP) and Conselho Nacional de Desenvolvimento Científico e Tecnológico (CNPq), Brazil.

\section{REFERENCES}

ANDERSON, C.; RATNIEKS, F.L.W. Task partitioning in insect societies. I. Effect of colony size on queueing delay and colony ergonomic efficiency. American Naturalist, v.154, n.5, p.521535, 1999. Available from: <http://www.journals.uchicago.edu/ doi/10.1086/303255>. Accessed: Jul. 15, 2016. doi: 10.1086/303255.

BOLLAZZI, M.; ROCES, F. Information needs at the beginning of foraging: grass-cutting ants trade off load size for a faster return to the nest. PloS one, v.6, n.3, p.e17667, 2011. Available from: <http:// journals.plos.org/plosone/article?id=10.1371/journal.pone.0017667>. Accessed: Jul. 15, 2016. doi: 10.1371/journal.pone.0017667.

BURD, M. Variable load size-ant size matching in leaf-cutting ants, Atta colombica (Hymenoptera: Formicidae). Journal of Insect Behavior, v.8, n.5, p.715-722, 1995. Available from: < http://link. springer.com/article/10.1007\%2FBF01997240>. Accessed: Jul. 15, 2016. doi: 10.1007/BF01997240.

BURD, M. Foraging performance by Atta colombica, a leaf-cutting ant. American Naturalist, v.148, n.4, p.597-612, 1996. Available from: $<$ http://www.journals.uchicago.edu/doi/abs/10.1086/285942>. Accessed: Jul. 15, 2016. doi: 10.1086/285942.

BURD, M. Body size effects on locomotion and load carriage in the highly polymorphic leaf-cutting ants Atta colombica and Atta cephalotes. Behavioral Ecology, v.11, n.2, p.125131, 2000. Available from: <http://beheco.oxfordjournals.org/ content/11/2/125.abstract $>$. Accessed: Jul. 15, 2016. doi: 10.1093/ beheco/11.2.125.

BURD, M. Leaf tissue transport as a function of loading ratio in the leaf-cutting ant Atta cephalotes. Ecological Entomology, v.26, n.5, p.551-556, 2001. Available from: <http://onlinelibrary.wiley. com/doi/10.1046/j.1365-2311.2001.00334.x/abstract >. Accessed: Jul. 15, 2016. doi: 10.1046/j.1365-2311.2001.00334.x.

BURD, M.; ARANWELA, N. Head-on encounter rates and walking speed of foragers in leaf-cutting ant traffic. Insectes Sociaux, v.50, n.1, p.3-8, 2003. Available from: <http://link. springer.com/article/10.1007\%2Fs000400300001>. Accessed: Jul. 15, 2016. doi: 10.1007/s000400300001.

BURD, M.; HOWARD, J.J. Optimality in a partitioned task performed by social insects. Biology letters, v.4, n.6, p.627629, 2008. Available from: <http://rsbl.royalsocietypublishing. org/content/4/6/627>. Accessed: Jul. 15, 2016. doi: 10.1098/ rsbl.2008.0398.

CLARK, E. Dynamic matching of forager size to resources in the continuously polymorphic leaf-cutter ant, Atta colombica (Hymenoptera, Formicidae). Ecological Entomology, v.31, n.6, p.629-635, 2006. Available from: <http://onlinelibrary.wiley.com/ 
doi/10.1111/j.1365-2311.2006.00826.x>. Accessed: Jul. 15, 2016. doi: $10.1111 / \mathrm{j} .1365-2311.2006 .00826 . \mathrm{x}$

DUSSUTOUR, A. et al. Individual and collective problem-solving in a foraging context in the leaf-cutting ant Atta colombica. Animal Cognition, v.12, n.1, p.21-30, 2009. Available from: <http://link. springer.com/article/10.1007\%2Fs10071-008-0165-0>. Accessed: Jul. 15, 2016. doi: 10.1007/s10071-008-0165-0

EVISON, S.E.F.; RATNIEKS, F.L.W. New role for majors in $\boldsymbol{A t t a}$ leafcutter ants. Ecological Entomology, v.32, n.5, p.451-454, 2007. Available from: <http://jeb.biologists.org/content/213/14/2357. long >. Accessed: Jul. 15, 2016. doi: 10.1242/jeb.031237.

FOURCASSIE, V. et al. Ant traffic rules. Journal of Experimental Biology, v.213, n.14, p.2357-2363, 2010. Available from: <http:// jeb.biologists.org/content/213/14/2357.long>. Accessed: Jul. 15, 2016. doi: $10.1242 /$ jeb.031237.

HART, A. et al. Task partitioning in leafcutting ants. Acta ethologica, v.5, n.1, p.1-11, 2002. Available from: < https://www. jstor.org/stable/4601905>. Accessed: Jul. 15, 2016. doi: 10.1007/ s10211-002-0062-5.

HART, A.G.; RATNIEKS, F.L.W. Task partitioning, division of labour and nest compartmentalisation collectively isolate hazardous waste in the leafcutting ant Atta cephalotes. Behavioral Ecology and Sociobiology, v.49, n.5, p.387-392, 2001a. Available from: $<$ http://link.springer.com/article/10.1007\%2Fs002650000312>. Accessed: Jul. 15, 2016. doi: 10.1007/s002650000312.

HART, A.G.; RATNIEKS, F.L.W. Leaf caching in the leafcutting ant Atta colombica: organizational shift, task partitioning and making the best of a bad job. Animal Behaviour, v.62, n.2, p.227234, 2001b. Available from: <http://www.sciencedirect.com science/article/pii/S0003347201917439>. Accessed: Jul. 15, 2016. doi: $10.1006 /$ anbe. 2001.1743

HELANTERA, H.; RATNIEKS, F.L. Geometry explains the benefits of division of labour in a leafcutter ant. Proceedings of the Royal Society B: Biological Sciences, v.275, n.1640, p.1255-1260, 2008. Available from: <http://rspb.royalsocietypublishing.org/content/275/1640/1255>. Accessed: Jul. 15, 2016. doi: 10.1098/rspb.2008.0024.

HOLLDOBLER, B.; WILSON, E.O. The ants. Harvard: Belknap Press of Harvard University, p. 732, 1990.

JEANNE, R.L. The evolution of the organization of work in social insects. Monitore Zoologico Italiano-Italian Journal of Zoology, v.20, n.2, p.119-133, 1986. Available from: <http:// www.tandfonline.com/doi/abs/10.1080/00269786.1986.107 36494? journalCode $=$ teee19>. Accessed: Jul. 15, 2016. doi: $10.1080 / 00269786.1986 .10736494$.

LEWIS, O.T. et al. Effects of trail gradient on leaf tissue transport and load size selection in leaf-cutter ants. Behavioral Ecology, v.19, n.4, p.805-809, 2008. Available from: <http://beheco. oxfordjournals.org/content/19/4/805.full.pdf + html $>$. Accessed: Jul. 15, 2016. doi: 10.1093/beheco/arn032.

LOPES, J.F. et al. The effect of trail length on task partitioning in three Acromyrmex species (Hymenoptera: Formicidae). Sociobiology, v.42, n.1, p.87-91, 2003. MOLL, K. et al. The energetics of running stability: costs of transport in grass-cutting ants depend on fragment shape. Journal of experimental biology, v.215, n.Pt 1, p.161-168,
2012. Available from: <http://jeb.biologists.org/content/215/1/161. long>. Accessed: Jul. 15, 2016. doi: 10.1242/jeb.063594.

OSTER, G.F.; WILSON, E.O. Caste and ecology in the social insects. Monographs in Population Biology, v.12. Princeton: Princeton University Press, 1978, 352 p.

RATNIEKS, F.L.W.; ANDERSON, C. Task partitioning in insect societies. II. Use of queueing delay information in recruitment. American Naturalist, v.154, n.5, p.536-548, 1999. Available from: <http://www.jstor.org/stable/10.1086/303256>. Accessed: Jul. 15, 2016. doi: 10.1086/303256.

ROCES, F. Leaf-cutting ants cut fragment sizes in relation to the distance from the nest. Animal Behaviour, v.40, n.6, p.1181-1183, 1990. Available from: <http://www.sciencedirect.com/science/ article/pii/S000334720580185X $>$. Accessed: Jul. 15, 2016. doi: 10.1016/S0003-3472(05)80185-X

RÖSCHARD, J.; ROCES, F. Cutters, carriers and transport chains: distance-dependent foraging strategies in the grass-cutting ant Atta vollenweideri. Insectes Sociaux, v.50, n.3, p.237-244, 2003a. Available from: <http://link.springer.com/article/10.1007 \%2Fs00040-003-0663-7>. Accessed: Jul. 15, 2016. doi: 10.1007/ s00040-003-0663-7.

RÖSCHARD, J.; ROCES, F. Fragment-size determination and size-matching in the grass-cutting ant Atta vollenweideri depend on the distance from the nest. Journal of Tropical Ecology, v.19, n.6, p.647-653, 2003b. Available from: <http://journals.cambridge. org/action/displayJournal?jid=TRO $>$. Accessed: Jul. 15, 2016. doi: $10.1017 / \mathrm{S} 0266467403006047$.

RUDOLPH, S.G.; LOUDON, C. Load size selection by foraging leaf-cutter ants (Atta cephalotes). Ecological Entomology, v.11, n.4, p.401-410, 1986. Available from: <http://onlinelibrary. wiley.com/doi/10.1111/j.1365-2311.1986.tb00319.x/abstract $>$. Accessed: Jul. 15, 2016. doi: 10.1111/j.1365-2311.1986.tb00319.x.

SCHWAB, N.V. et al. Foraging by Atta sexdens (Formicidae: Attini): seasonal patterns, caste and efficiency. Ecological Entomology, v.4, n.11, p.239-247, 1979. Available from: <http:// onlinelibrary.wiley.com/journal/10.1111/(ISSN)1365-2311>. Accessed: Jul. 15, 2016. doi: 10.1111/j.1365-2311.1979.tb00581.x.

WETTERER, J.K. Allometry and the geometry of leaf-cutting in Atta cephalotes. Behavioral. Ecology and Sociobiology, v.29, n.5, p.347-351, 1991. Available from: <http://link.springer.com/ article/10.1007/BF00165959>. Accessed: Jul. 15, 2016. doi: 10.1007/BF00165959.

WILSON, E.O. The insect societies. Cambridge, Massachusetts, USA: Harvard University, 1971. 732p.

WILSON, E.O. Caste and division of labor in leaf-cutter ants (Hymenoptera: Formicidae: Atta) II. The ergonomic optimization of leaf cutting. Behavioral Ecology and Sociobiology, v.7, n.2, p.157165, 1980a. Available from: <http://www.jstor.org/stable/4599320>. Accessed: Jul. 15, 2016. doi: 10.1007/BF00299521.

WILSON, E.O. Caste and division of labor in leaf-cutter ants (Hymenoptera: Formicidae: Atta). Behavioral Ecology and Sociobiology, v.7, n.2, p.143-156, 1980b. Available from: <http:// link.springer.com/article/10.1007/BF00299520>. Accessed: Jul. 15, 2016. doi: 10.1007/BF00299520. 